УДК 373.2.015.31:159.93

DOI:

Олександра Свйонтик, кандидат педагогічних наук, викладач кафедри загальної педагогіки та дошкільної освіти Дрогобицького державного педагогічного університету імені Івана Франка

\title{
СЕНСОРНЕ ВИХОВАННЯ ЯК ОСНОВА РОЗУМОВОГО РОЗВИТКУ ДІТЕЙ ДОШКІЛЬНОГО ВІКУ
}

У статті розкривається сутність понять про сенсорний розвиток, сенсорну культуру, сенсорне світосприймання. Проведено аналіз досліджень педагогів та психологів у особливостях розумового розвитку дошкільника. Виокремлено важливість переосмислення кращього доробку педагогів-практиків для врахування у методичній організачії діяльності.

Запропоновано для обговорення проблему виховання дітей дошкільного віку з позиції індивідуального способу впливу, визначено переваги процесу саморозвитку дитини за допомогою спеціального дидактичного матеріалу. Наголошено на необхідності створення позитивної емоичійної атмосфери у роботі з доикільниками, яку створює педагог. Підкреслено необхідність оволодіння методичними знаннями педагогів у процесі організаиії діяльності з дочкільниками на шляху їх поступального саморозвитку.

Описано “дари Фребеля” і подано методичні рекомендації для процесу організації діяльності педагога з дітьми дошкільного віку в умовах ЗДО. Через коментарі відомих педагогів щуодо використання у педагогічній діяльності сенсорного матеріалу М. Монтессорі підкреслено необхідність проведення спеціальних занять для підготовки педагогів до правильного застосування системи дидактичних вправ з дошкільниками, популяризації філософських засад Монтессорі педагогіки у просвітницькій роботі з батьками вихованців.

Ключові слова: сенсорний розвиток; сенсорне виховання; дидактичний матеріал; сенсорна культура; спеціальне розвивальне середовище; розумовий розвиток.

Jim. 10.

Oleksandra Sviontyk, Ph.D.(Pedagogy), Lecturer of General Pedagogy and Preschool Education Department Drohobych Ivan Franko State Pedagogical University

\section{SENSORY EDUCATION AS A BASIS OF MENTAL DEVELOPMENT OF PRESCHOOL CHILDREN}

The article reveals the essence of the concepts of sensory development, sensory culture, and sensory worldview. The analysis of researches of pedagogues and psychologists in features of mental development of the preschooler is carried out. The importance of rethinking the best achievements of pedagogues-practitioners for consideration in the methodological organization of activities is highlighted.

The problem of upbringing preschool children from the standpoint of an individual method of influence is presented for discussion, the advantages of the process of child self-development with the help of special didactic material are determined. The need to create a positive emotional atmosphere in working with preschoolers, which is created by the teacher, is emphasized. The need to master the methodological knowledge of pedagogues in the process of organizing activities with preschoolers on the path of their progressive self-development is emphasized.

The article describes the "gifts of Froebel" and provides guidelines for the process of organizing the activities of teachers with preschool children in the conditions at the Institution of Preschool Education. Through the comments of well-known pedagogues on the use of Montessori sensory material in teaching, the need for special classes to prepare teachers for the proper use of didactic exercises with preschoolers, popularization of philosophical principles of Montessori pedagogy in educational work with parents is underlined.

Keywords: sensory development; sensory education; didactic material; sensory culture; special developmental environment; mental development.

П остановка проблеми у загальному вигляді. Актуальною є проблема модернізації змісту дошкільної освіти як першої та важливої ланки у системі отримання освіти особистістю. Базова програма розвитку дитини дошкільного віку "Я у Світі" орієнтує усіх учасників освітнього процесу (керівників, педагогів, психологів, батьків вихованців, методистів, громадськість) на оновлення розвивального середовища відповідно до сфер та ліній розвитку дитини: “...створення творчої, розвивальної атмосфери, емоційно позитивного середовища сприяють задоволенню та розвитку пізнавальних інтересів дошкільників, урізноманітнюють і наповнюють емоціями життєдіяльність, формують інтерес до пошукової діяльності” $[1,4]$.

Технологічний та соціальний прогрес створює передумови для інтеграції знань і вироблення 
стратегії у використанні нових форм навчальної комунікації. Сенсорний розвиток такий що є у загальному процесі зростання дошкільника, виступає актуальним у створенні розвивального середовища. Функція педагога набуває нового спрямування, стає фасилітатором у процесі організації освітнього процесу, а від його вміння застосовувати індивідуальні та групові форми роботи на заняттях $з$ дидактичним матеріалом, який є стає способом сенсорного виховання дошкільника, сприяє створенню позитивної емоційної атмосфери, задовольняє пізнавальний та дослідницький інтерес.

Аналіз останніх досліджень і публікацій. Над проблемою осучаснення і використання здобутків зарубіжної та вітчизняної педагогіки у сфері дошкільного виховання працюють психологи (Т. Дуткевич, О. Кононко, С. Кулачківська, С. Ладивір, Р. Павелків, Т. Піроженко та ін.), які обгрунтовують врахування особливостей вікових та психічних можливостей дитини на шляху пізнання світу; педагоги (А. Богуш, Н. Гавриш, I. Карабаєва, К. Крутій, Н. Лисенко, О. Лінник, О. Рейнпольська, 3. Плохій, Т. Поніманська та ін.), які розробляють технології та методики використання сенсорного простору для розвитку у дітей розумової сфери за допомогою відчуттів і у процесі дослідної діяльності. Науковці та педагоги-практики, розробляючи Базовий компонент дошкільної освіти, визначили організацію розвивального середовища в ЗДО як один із пріоритетних напрямів у здійсненні процесу гармонійного розвитку дитини і одну із семи ліній розвитку дошкільника програми “Я у Світі” (2019) присвячено саме проблемі організації і використанні сенсорного середовища як основного у формуванні розумової діяльності.

Виділення невирішених раніше частин загальної проблеми. В умовах української дошкільної освіти проблема якісної організації освітнього процесу для створення сприятливих умов у розвитку дитини за допомогою відчуттів (сенсорики) подаються у авторських розробках методистів. Наприклад, за допомогою образотворчого мистецтва (І. Бабій, Н. Дяченко, I. Ликова, Н. Сех та ін.); на основі використання логіко-математичного матеріалу (Л. Ільченко, А. Конорович, Ю. Мурашевич, Н. Рудницька, Н. Тарнавська, Н. Чернега та ін.). Пропонуємо повернутися до переосмислення кращого досвіду корифеїв дошкільної педагогіки Ф. Фребеля та М. Монтессорі, які розробили спеціальний дидактичний матеріал, який став основою для саморозвитку дошкільників, що є важливим у сучасному освітньому процесі, де акцентуються способи індивідуального поступального, пізнавального інтересу дитини дошкільного віку у процесі організації діяльності.

Мета статті: обгрунтувати принципи та методичні засади у використанні освітнього простору у формуванні сенсорної культури дітей дошкільного віку в умовах діяльності ЗДО.

Виклад основного матеріалу. Дошкільне дитинство є унікальним періодом розвитку особистості, тому увага сучасних теоретиків та практиків звернена на вивчення психологічний умов сприятливого індивідуального розвитку особистості дитини, а вдосконалення сенсорики дошкільників $€$ важливим у процесі світосприймання.

Великий внесок у дослідження теорії та практики сенсорного розвитку дітей дошкільного віку здійснили вчені: Ф. Фребель, М. Монтессорі, Р. Штайнер, Л. Венгер [2], Л. Божович Л. Виготський [3], О. Запорожець, І. Дичківська [4], Т. Михальчук, О. Кононко [2] та ін., які вивчаючи особливості розвитку особистості дошкільника, враховували формування знань за допомогою емоційно-чуттєвого сприймання. Л. Виготський стверджував: "Індивідуальність дитини зумовлена її природними особливостями - різноманітними комбінаціями людських генів, деякими анатомо-фізіологічними особливостями організму, головного мозку, органів чуття, а також типологічними властивостями нервової системи, іншими словами, типом вищої нервової діяльності”, $[3,19]$.

Термін “сенсорика” походить від латинського слова “sensus", що перекладається як відчуття, як “родар” сприйняття людиною навколишнього світу [9, 14]. За визначенням К. Юнга “сенсорика - це відчуття, які має людина при контакті зі світом, це конкретні об'єкти, які сприймаються на рівні чуття і демонструються та описуються через моторно-рухову діяльність" $[9,17]$.

Виходячи з визначень, що сенсорне сприймання $\epsilon$ джерелом надходження інформації про світ через органи відчуття (нюх, слух, зір, дотик, смак), можемо зробити припущення, що основою формування світосприймання та світорозуміння у період дошкільного дитинства є синтез різних відчуттів, надання їм форм мовленнєвих понять, назв, визначення їх змістових умов застосування для практичного використання у життєдіяльності.

У ранньому дитинстві сенсорні знання надаємо у певні моменти прояву інтересу дитини. Такі вправи не мають системного характеру, бо ще немає необхідності знайомити дітей iз загальноприйнятими сенсорними еталонами. Однак проведення дидактичних вправ із сенсорного розвитку готують грунт для 
подальшого засвоєння сенсорних еталонів через мимовільне запам'ятовування.

До досягнення дитиною трирічного віку накопичуються сенсорні знання з кольорової гами, дитина може виконувати завдання за задумом. Наприклад, вивчаючи властивості кольорової гами у змішуванні певних кольорів, дитина знає, що жовтий і синій дають зелений відтінок (пряме навчання), дитині пропонується палітра основних кольорів для експерименту і з'ясування інших комбінацій кольору (автодидактична вправа). Педагог та вихованець обговорюють відкриття дитиною нових можливостей комбінації кольору, як їх можна застосувати тощо. Таким чином, дитина здобуває за допомогою сенсорики знання, вчиться експериментувати, проєктує наступну діяльність із використаним досвідом.

Сенсорний розвиток, коли дитина досягла середнього дошкільного віку, має якісні показники умінь відрізняти відтінки колірної гами, різноманітність смаків, запахів і звуків, становить основу естетичного розвитку, а у подальшому сприяє формуванню уяви та відчуття прекрасного у навколишньому світі. Позаяк саме із сприйняттям предметів і явищ навколишнього світу починається пізнання, а сенсорне виховання стає базою для розумового та естетичного розвитку дитини у наступні роки, адже інтелектуальний розвиток (запам'ятовування, мислення, уява) опирається на "розум рук і очей" (за М. Монтессорі).

Пісня, танець, музичний супровід $є$ додатковим стимулом позитивних вражень. Педагог повинен урізноманітнювати й активізувати процес пізнання i засвоєння нового, мати спокійний та доброзичливий вигляд, бути готовим підтримати ініціативу дітей в урізноманітненні діяльності.

У сенсорному вихованні $є$ низка завдань, які формують сенсорну культуру, бо в процесі дій та вправ 3 предметами дитина вчитися розрізняти властивості навколишнього світу. Перші ігри та вправи повинні закріплюватися практичними діями, що вимагають опори на форму і колір предметів. Діти часто виконують вправи за зразком.

Ф. Фребель (1782-1852) великого значення надавав питанням сенсорного розвитку дитини і розробив систему дидактичних матеріалів, які мали назву “дари Фребеля”, відобразили системну спробу диференціювати дидактичні матеріали для формування знань за допомогою сенсорних вправ у дошкільників. Цей дидактичний матеріал призначений для ознайомлення і вироблення уявлень про форму, величину, просторові відношення, числа, систему занять на основі гри, яку організовує у синхронному виконанні 3 дошкільниками педагог. Діти проговорюють особливості предметів, досліджують їх, моделюють, що сприяє розумовому розвитку на основі сенсорного досвіду. Дитина, на думку педагога, “наділена, крім основних інстинктів, інстинктом пізнавальним, дослідницьким, що $є$ основою до навчальної діяльності, де грунтом має стати досвід роботи з предметами певної форми, розміру, властивостей” $[9,91]$.

Дидактична система Ф. Фребеля має спеціальний матеріал. "Першим даром” $є$ в'язані кольорові парні кульки, які мають методику презентації через приспівування авторських віршиків у процесі ранкової зустрічі. “Другий дар” - набір дерев’яних об'ємних фігур (куля, два куби, циліндр), з яким діти знайомляться у вправах за зразком діяльності педагога, який у віршованій формі під наспіви пропонує виконувати завдання. Діти мають такі ж фігури, які підвішено на рухомих кріпленнях до рамочки, щоб бачити відмінності, розуміти просторовість форм, порівнювати 3 предметами які $є$ у вжитку. Наступні дари: набір чисел із дерев'яних кубиків, планшети для шнурування, набори геометричних об'ємних фігур чітких кольорів, палички для лічби тощо є засобами формування розумового розвитку, диференціюються за кольором, розміром, формою, забезпечують індивідуальні умови засвоєння знань. Так, у процесі самостійного поступального розвитку є завдання для геометричних наборів за зразком, зображених на малюнку. Для саморозвитку у методиці служить момент виправлення помилок, коли педагог пропонує виконану дитиною роботу зіставити з конструкцією у книзі (зразок) та сам конструює правильну будівлю. Дитина аналізує свою роботу, педагога і зображення. Важливо не допомагати, не втручатися у баченні дитиною конструкцій, а вичікувати моменту самостійного розумового зростання (відповідність еталону). Наступним $є$ момент творчості: діти за довільними бажаннями створюють споруди, презентують їх, умовно дарують тому, хто їм сьогодні важливий.

Поняття “сенсорної культури” запроваджено в педагогіку завдяки дослідженням відомої італійської педагогині М. Монтессорі (1870-1952), яка розробила одну з кращих авторських систем виховання дошкільників. Таким чином, через системний вплив на процес становлення суб'єктивних уявлень про навколишній світ у дитини за допомогою органів чуття і формування об'єктивних понять становить сенсорну культуру. М. Монтессорі писала: "без розвинутих органів 
чуття не може бути інтелекту і вихованої людини" $[9,19]$. Розроблений педагогом дидактичний матеріал та методи роботи з ним мають чіткі правила, що допомагає не просто вказувати дитині на якості предметів і явищ навколишнього світу, а створює умови для самостійного освоєння відмінностей, порівняння, зіставлення, уможливлює процес фіксації знань у довготривалій пам'яті, набувати досвіду і робити відкриття.

Дитина самостійно, за допомогою спеціальних предметів, які розміщені в одній із п’яти зон розвитку - сенсорній, отримують уявлення про чіткі властивості кольору, звуку, форми, розміру. Дошкільник споглядає, досліджує і робить висновки, надає змісту отриманим відчуттям, що $\epsilon$ важливішим у розвитку мислення, ніж словесні знання чи факти, які повідомляє педагог.

Система сенсорного виховання М. Монтессорі має поняття “сенсорної культури”, в якому визначено поетапний процес об'єктивізації знань про навколишній світ та його властивості через суб'єктивне сприймання. Погоджуючись із твердженнями М. Монтессорі, сучасні дослідники узагальнюють зміст поняття і роблять акцент на способі отримання цієї культури, даючи таке визначення: “Сенсорна культура - це загальноприйняті суспільством уявлення про колір, форму та інші властивості предметів, які формуються у дошкільників на рівні елементарних уявлень про світ через гру, працю, навчання, самостійні діï” [4, 47]. “Сенсорна культура дитини $\epsilon$ результатом засвоєння нею знань про світ за допомогою органів чуття у віці, коли пізнання відбувається на основі предметно-образної дії' [4, 49]. Таким чином, дитина пізнає світ, набуває досвіду, рухається шляхом від суб'єктивного досвіду до об'єктивних понять, виробляє стереотипи та здійснює узагальнення, усвідомлює наслідки дій з предметами, засвоює правила, що становить основу розумового розвитку.

Визначаючи дошкільний вік як особливий у здобутті сенсорного досвіду, самостійності та розвитку мислення, послідовниця педагогіки М. Монтессорі Ю. Фаусек писала: “Якщо вихователь не зумів пробудити інтерес до пізнання через самостійну діяльність 3 предметами, дослідження та спостереження, коли у дитини лише починає пробуджуватися спостережливість до навколишнього, яка має таке величезне значення для психологічного життя людини, то розумові здібності дитини поступово притуплюються, i, ставши школярем, дитина буде байдуже дивитися на світ" $[9,12]$.

Л. Венгер (1923-2004) поділив процес сенсорного виховання у дошкільному віці на підготовчий етап (перші три роки життя), коли вивчення якостей матеріалів має спонтанний характер і систематичне засвоєння дитиною сенсорної культури, починаючи 3 молодшого дошкільного віку, коли мислення дитини дозволяє логічно зіставляти, виокремлювати, узагальнювати, отримані знання і застосовувати їх у подальших діях. Спеціально організоване розвивальне середовище із набором предметів із сенсорними ознаками дає змогу дитині під наглядом педагога проводити самостійні дослідження, здійснювати обстеження [2, 32].

О. Запорожець (1905-1981), займаючись експериментальними дослідженнями процесів сенсорного розвитку дошкільників, обгрунтував необхідність формування сенсорних здібностей дітей через “поступальне їх самонавчання: обстеження предметів, узагальнення знань, спосіб асоціативного порівняння, перенесення засвоєних способів дій в нові умови, на нові предмети" [7, 24]. Це дає можливість дітям самостійно мислити, експериментувати, орієнтуватися у різноманітних властивостях нових предметів. Н. Поддьяков (1929-2021) зазначає, що “при цьому деякі властивості і сторони явищ можуть сприйматися недостатньо чітко, або не сприйматися зовсім, тому наступний чуттєвий досвід потребує вдосконалення та розвитку у навчально-виховного процесі [7, 31], що підкреслює вікові особливості розвитку дитини і важливість індивідуального та поступального здобуття знань про світ через сенсорний досвід, а також етапність зростання мисленнєвих процесів у дитячому розвитку від предметночуттєвого до образного.

Висновки. Сенсорне виховання - педагогічно організоване та психологічно обгрунтоване цілеспрямоване вдосконалення, розвиток у дітей сенсорних процесів (відчуттів, сприймань, уявлень), яке здійснюється у спеціально створеному предметному середовищі і проходить під керівництвом педагога, а також має продовження у практичному житті дитини, в процесі ігор, праці, під час якого відбувається цілісне сприйняття дитиною різних явищ i предметів навколишнього світу.

Процесом сенсорного розвитку дитини у період дошкільного дитинства як специфічно сприятливого до цього прогресу займалися відомі дослідники педагогіки та психології, а починаючи 3 початку XX ст., дослідженням особливостей сенсорних процесів у освітній практиці на основі наукових досягнень почали здійснюватися методичні розробки та розроблятися рекомендації для керування у процесі діяльності педагогів. 
Подальше вивчення та інтеграція знань у розвитку сенсорної культури дошкільників може стати цінним методичним матеріалом для педагогівпрактиків та батьків дітей дошкільного віку. Вважаємо, що важливим є узагальнення і надання змісту понятійній базі, де буде уточнено поняття, які мають місце у загальному емоційночуттєвому розвитку дошкільника і презентовані у науковій літературі з позиції авторських підходів.

\section{ЛІТЕРАТУРА}

1. Базова програма розвитку дитини дошкільного віку “Я у Світі”. М-во освіти і науки України, Акад. пед. Наук України; наук. ред. та упор. О.Л.Кононко. Київ: Світич, 2008. 430 с.

2. Венгер Л. А., Пилюгина Э. Г., Венгер Н. Б. Воспитание сенсорной культуры ребенка. Москва: Просвещение, 1988. 143 с

3. Виготский Л.С. Педагогическая психология / за ред. В.В. Давидова. Москва: Педагогика. $1991.480 \mathrm{c}$

4. Дичківська I.M., Поніманська T.I. М. Монтессорі: теорія і технологія.Сенсорнопізнавальний розвиток дітей раннього віку, як передумова формування обдарованої особистості. Освіта та розвиток обдарованої особистості. №11 (18)/11/2013. C.47-52

5. Дошкільна педагогіка: навчальний підручник / під ред. Т.І.Поніманської. Київ: Академвидав, 2006. $360 \mathrm{c}$.

6. Павелків Р., Цигипало О. Дитяча психологія: навч. посіб. для самостійної роботи студента. Київ: Академвидав, 2011. 376 с.

7. Розумне виховання сучасних дошкільнят: Методичний посібник/ Н. Гавриш, О. Брежнєва, І. Кіндрат, О. Рейнпольська, Київ: “Слово”, 2015. $176 \mathrm{c}$.

8. Сенсорний розвиток: 3 досвіду роботи. 56(7) років/ Авт.-упоряд. М. Л. Кривоніс, О. Л. Дроботій. Харків: Видавництво “Ранок”, 2012.256 с.

9. Чепіль М., Дудник Н. Педагогіка Марії Монтессорі: навч-метод. посіб. Київ: “Слово”, $2017.314 \mathrm{c}$.

\section{REFERENCES}

1. Bazova prohrama rozvytku dytyny doshkilnoho viku "Ia u Sviti" [Basic program of preschool child development "I am in the World"]. Ministry of Education and Science of Ukraine, Acad. ped. Sciences of Ukraine; (Ed.). O.L.Kononko. Kyiv, 2008. 430 p.[in Ukrainian].

2. Venger, L. A., Pilyugina, E. G. \& Venger, N. B. (1988). Vospitanie sensornoy kultury rebenka [Fostering a child's sensory culture]. Moscov, 143 p. [in Russian].

3. Vigotskiy, L.S. (1991). Pedagogicheskaya psikhologiya [Pedagogical psychology]. (Ed.).V.V. Davidova. Moscov, 480 p. [in Russian].

4. Dychkivska, I.M. \& Ponimanska, T.I. (2013). M. Montessori: teoriiai tekhnolohiia. Sensorno-piznavalnyi rozvytok ditei rannoho viku, yak peredumova formuvannia obdarovanoi osobystosti [M. Montessori: the theory and technology. The sensory-cognitive development of young children as a prerequisite for the formation of a gifted personality]. Education and development of a gifted personality. No.11 pp.47-52. [in Ukrainian].

5. Doshkilna pedahohika: navchalnyi pidruchnyk [Preschool pedagogy: a textbook]. (Ed.). T.I.Ponimanska. Kyiv, 2006. 360 p. [in Ukrainian].

6. Pavelkiv, R. \& Tsyhypalo, O. (2011). Dytiacha psykholohiia: navch. posib. dlia samostiinoi roboty studenta [Child psychology: textbook. way. for independent work of the student]. Kyiv, 376 p. [in Ukrainian].

7. Havrysh, N., Brezhnieva, O., Kindrat, I. \& Reinpolska, O. (2015). Rozumne vykhovannia suchasnykh doshkilniat: metodychnyi posibnyk [Smart education of modern preschoolers: methodical manual]. Kyiv, 176 p. [in Ukrainian].

8. Sensornyi rozvytok: $z$ dosvidu roboty. 5-6(7) rokiv [Sensory development: from work experience. 5-6 (7) years]. (Ed.). M. L. Kryvonis \& O. L. Drobotii. Kharkiv, 256 p. [in Ukrainian].

9. Chepil, M. \& Dudnyk, N. (2017). Pedahohika Marii Montessori: navch-metod. posib. [Pedagogy of Maria Montessori: teaching method. aid.]. Kyiv, 314 p. [in Ukrainian].

Стаття надійшла до редакції 22.12.2020

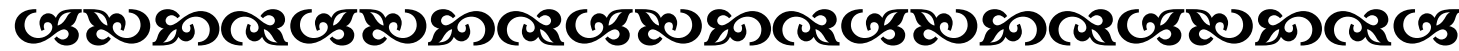

"Тродовжуючи себе в свойх вихованиях, ми творимо не тільки людину. Ми творимо самий час. Dух часу, взаємовідносини міжлюдьми - все ие залежить від того які ми $з$ вами, від того якою має бути школа, що бормує безмірно складне і невичерпно преқрасне - гармонійно розвинену людсьқу особистість".

Василь Сухомлинський педагог, публіиист, письменник, поет

\section{G580}

